\title{
Organizational Behavior in SME-Family Companies in the City of Maracaibo, Venezuela
}

\author{
Pasquale Raspa D'Inzeo', Danny Daniel López Juvinao ${ }^{2 *}$ and Fabio Orlando Moya Camacho² \\ 'URBE, Rafael Belloso Chacín University, Maracaibo, Venezuela; praspa@gmail.com \\ 2IPAITUG, La Guajira University, Riohacha, Colombia; fmoya@uniguajira.edu.co, dlopezj@uniguajira.edu.co
}

\begin{abstract}
Objectives: The purpose of this article is to analyze the SME-family businesses organizational behavior in the city of Maracaibo. Materials and Methods: The research type was descriptive, with no experimental, transectional, field design. The population consisted of eleven (11) managers and seventy-five (75) employees. The information was collected with a questionnaire with forty-two (42) reagents, validated by experts and with an Alfa Cronbach reliability of 0.826. The results analysis was descriptive with arithmetic frequencies distribution and means percentage. Results: The organizational behavior within the SME-Familiar companies is not adequate, characterized by a bureaucratic design, with a centralized authority, making it difficult to develop innovative activities that favor a work environment oriented towards the organizational objectives achievement. Application/Improvements: To improve the situation observed through the adoption of an organizational matrix-type design oriented to the authority decentralization, thereby improving the personnel supervision and the organizational objectives achievement.
\end{abstract}

Keywords: Family Business, Organizational Behavior, Organizational Design, Organizational Structure, Psychological Variables, Small and Medium Enterprises (SMEs)

\section{Introduction}

At the global level, most of the competing companies are of a family nature regardless of the size they may have. This reality is repeated in Venezuela, categorized most of these organizations as Small and Medium Enterprises (SMEs), where in almost all cases the shares majority belongs to a person or a family members group. This SME-Family binomial is constituted as an important economy pillar $\stackrel{1}{\text {. }}$.

This is how in our society, a large part of the production process is carried out through this companies type, which like other companies types require favorable environments where workers are satisfied with their productivity. However, today there are still organizations that do not give enough importance to the workplace, being a great importance aspect in the strategic development of any organization ${ }^{2}$.

${ }^{*}$ Author for correspondence
It is therefore necessary to focus on the beneficiaries, develop a clear vision of where you want to go, manage systematic methods with realistic bases, set specific clear goals for improvement, work as a team, in order to finally evaluate and monitor progress for achievements previously established, all through proper organizational behavior.

Understand organizational behavior, such as the systematic acts and attitudes study that people show in organizations. In this sense, the CO systematically studies the acts (or behaviors) and attitudes, which are employees performance fundamental determinants as they influence the organization productivity and therefore the results quality and quantity that each employee produces ${ }^{3}$.

This requires that managers worry about their employee's satisfaction with their jobs for three reasons. First: because it is possible that there is a link between satisfaction and productivity. Second: satisfaction is 
negatively related to absenteeism and turnover. Finally: it can be argued that managers have a humanist responsibility to provide their employees with stimulating, intrinsically remunerated and satisfactory jobs ${ }^{3}$.

Sustained in the above considerations, organizational behavior is an element that must be considered and studied within organizations regardless of their characteristics. However, in Latin America, most of the models that have been applied for their analysis are incongruent with the local context, becoming major failures, especially within organizations where the organizational actor's daily lives face diverse conditions ${ }^{4}$.

Similar situations are evident in SME-Family companies in the city of Maracaibo, where organizational structures individualities and characteristics have been evidenced that make a factors series that affect the behavior of each person and generate conflicts that arise from a or otherwise affect the organization behavior and its work environment.

Hence, it has been decided to develop a study with the purpose of analyzing the organizational behavior in SMEfamily companies in the city of Maracaibo, Venezuela. Establishing as specific objectives to identify the staff individual psychological variables, to describe the organizational design types and verify the organizational structure elements.

\section{Materials and Methods}

The research is located within the descriptive type ${ }^{5}$, with a non-experimental, transectional and field design ${ }^{6}$. Six (6) SME-Family companies located in the city of Maracaibo, Zulia State, were considered as the study population (Table 1). The population was considered finite and accessible, therefore it was assumed as a population census.

As a data collection technique, the survey $y^{7}$ was selected and as a tool a scale questionnaire with five (5) closed response alternatives (always, almost always, sometimes, almost never and never), containing forty-two (42) reactive, validated by experts and the reliability calculated with the Cronbach's Alpha coefficient, yielding a value of 0.826 indicating high reliability $\stackrel{8}{\text {. }}$

Regarding the results analysis and information processing, descriptive statistics were used with percentage frequencies distribution and arithmetic means ${ }^{9}$. In the same way, a scale was designed (Table 2) for the means interpretation.

\section{Results and Discussion}

In reference to the Individual Psychological Variables Dimension (Table 3), it can be observed in Table 1, that the majority of managers, represented $46.23 \%$, chose the option always, followed by $45.43 \%$ who chose the alternative almost always, On the other hand, $7.55 \%$ said sometimes, $1.78 \%$ never and $0.75 \mathrm{almost}$ never. In the case of employees, the results were different in their answers, because $40.03 \%$ opted for the option never, $36.15 \%$ almost never, $9.89 \%$ sometimes, $3.55 \%$ almost always and $2.65 \%$ always.

On the other hand, the arithmetic mean average was 2.08 for the employees, placing them in the Unsuitable category and 3.59 for the managers, which was placed in the adequate category, according to the scale for the means categorization. With these results, discrepancy with Davis and Newstrom ${ }^{10}$ shows that people have much in common, but there are also differences between them; which requires that the superior treatment to his staff must obey the knowledge of the personality, perception and attitudes variables, as well as their relationship in the work behavior, since through them it will be possible to understand the behaviours reason and to use mechanisms that allow conducting the proceedings.

Under the same perspective, Chiavenato ${ }^{2}$ states that each person is a multidimensional phenomenon, which is

Table 1. Population distribution

\begin{tabular}{lll}
\hline SME-Familiar Company & Managers & Employees \\
\hline Company A & 1 & 8 \\
Company B & 2 & 12 \\
Company C & 2 & 9 \\
Company D & 1 & 9 \\
Company E & 3 & 21 \\
Company F & 2 & 16 \\
Total & $\mathbf{1 1}$ & $\mathbf{7 5}$ \\
\hline
\end{tabular}

Table 2. Means interpretation

\begin{tabular}{ll}
\hline Rank & Categories \\
\hline $4,20<\mathrm{X} \leq 5,00$ & Very Suitable \\
$3,40<\mathrm{X} \leq 4,20$ & Suitable \\
$2,60<\mathrm{X} \leq 3,40$ & Few suitable \\
$1,80<\mathrm{X} \leq 2,60$ & Unsuitable \\
$1,00 \leq \mathrm{X} \leq 1,80$ & Very Unsuitable \\
\hline
\end{tabular}


subject to a huge number variable influences, which can be improved and modified over time.

These have a great effect on the way people think and act, so they are presumed to intervene directly in decision making and conflict resolution. For the foregoing, it follows that the manager must receive a preparation as comprehensive as possible that allows not only develop knowledge and skills to exercise their function, but must also receive a psycho-emotional preparation that allows him to adequately address the work pressure to which is subjected daily

In the Organizational Design types dimension (Table 4), it can be observed that the highest resulting value for managers is located in the alternative always with $57.41 \%$, followed almost never with $24.07 \%$, almost always with $9.26 \%$, never with $5.56 \%$ and sometimes with $3.70 \%$. On the other hand, for the employees the values were $45.75 \%$ in always, $15.86 \%$ in never and $15.55 \%$ in always, $14.51 \%$ in sometimes and $9.31 \%$ in almost never.

The means average values were of 3.90 for the managers indicating that the organizational design types are Adequate, while for the employees; the average value was of 2.95, coinciding with the category 'Not Adequate.'
In this sense, discrepancies can be observed between the opinions of both populations (managers and employees) with respect to the simple structure indicator, where the managers express that the organizations studied do not have these characteristics, while the employees do identify the simple structure as an organizational design type of these organizations, characterized according to Robbins and Decenzo ${ }^{11}$ by a structure that has little labor specialization and a centralized authorities in a single person.

On the other hand, with respect to the matrix structure indicator, there are also differences between the opinions of both populations, where managers identify this design type, while employees say that these characteristics are not adequate in these organizations since the manager assumes according to Robbins ${ }^{3}$ mainly the responsibilities of his position without requesting or having the collaboration or support of other departments or experts for their activities development.

Where there is an opinions coincidence is with respect to the bureaucratic organizational design type, evidencing to agree that they are characterized according to Chiavenato ${ }^{2}$ for their highly routine operational tasks,

Table 3. Individual psychological variables dimension

\begin{tabular}{|c|c|c|c|c|c|c|c|c|c|c|c|c|}
\hline \multirow[b]{3}{*}{ Indicators } & \multicolumn{10}{|c|}{ Alternatives (\%) } & \multirow{2}{*}{\multicolumn{2}{|c|}{ Means }} \\
\hline & \multicolumn{2}{|c|}{ Always } & \multicolumn{2}{|c|}{ Almost Always } & \multicolumn{2}{|c|}{ Sometimes } & \multicolumn{2}{|c|}{ Almost Never } & \multicolumn{2}{|c|}{ Never } & & \\
\hline & Man. & Emp. & Man. & Emp. & Man. & Emp. & Man. & Emp. & Man. & Emp. & Man. & Emp. \\
\hline Perception & 60,2 & 4,1 & 36,6 & 4,2 & 3,1 & 15,1 & 0,0 & 49,0 & 0,0 & 27,7 & 3,65 & 1,27 \\
\hline Attitudes & 46,6 & 0,0 & 53,3 & 6,9 & 0,0 & 4,0 & 0,0 & 52,9 & 0,0 & 36,2 & 3,48 & 2,00 \\
\hline Personality & 64,7 & 3,1 & 30,0 & 0,5 & 5.3 & 10,3 & 0,0 & 29,7 & 0,0 & 56,4 & 3.62 & 2,59 \\
\hline $\begin{array}{l}\text { Emotional } \\
\text { Intelligence }\end{array}$ & 13,4 & 3,4 & 61,8 & 2,6 & 21,8 & 10,1 & 3,0 & 13,0 & 7,1 & 63,8 & 3,61 & 2,45 \\
\hline Average & 46.23 & 2.65 & 45.43 & 3.55 & 7.55 & 9.89 & 0.75 & 36.15 & 1.78 & 40.03 & 3.59 & 2.08 \\
\hline
\end{tabular}

Table 4. Organizational design type's dimension

\begin{tabular}{|c|c|c|c|c|c|c|c|c|c|c|c|c|}
\hline \multirow[b]{3}{*}{ Indicators } & \multicolumn{10}{|c|}{ Alternatives (\%) } & \multirow{2}{*}{\multicolumn{2}{|c|}{ Means }} \\
\hline & \multicolumn{2}{|c|}{ Always } & \multicolumn{2}{|c|}{ Almost Always } & \multicolumn{2}{|c|}{ Sometimes } & \multicolumn{2}{|c|}{ Almost Never } & \multicolumn{2}{|c|}{ Never } & & \\
\hline & Man. & Emp. & Man. & Emp. & Man. & Emp. & Man. & Emp. & Man. & Emp. & Man. & Emp. \\
\hline Simple Structure & 0.00 & 64.73 & 0.00 & 24.15 & 11.11 & 12.12 & 72.22 & 0.00 & 16.67 & 0.00 & 1.94 & 3.40 \\
\hline Bureaucracy & 83.33 & 70.04 & 16.67 & 21.26 & 0.00 & 8.34 & 0.00 & 0.00 & 0.00 & 0.00 & 4.83 & 3.35 \\
\hline Matrix Structure & 88.89 & 2.50 & 11.11 & 1.25 & 0.00 & 20.73 & 0.00 & 27.94 & 0.00 & 47.58 & 4.94 & 2.11 \\
\hline Average & 57.41 & 45.75 & 9.26 & 15.55 & 3.70 & 14.51 & 24.07 & 9.31 & 5.56 & 15.86 & 3.90 & 2.95 \\
\hline
\end{tabular}


with centralized authority, with little control breadth and with a decision process linked to the command chain.

In the Organizational structure elements dimension (Table 5), it is observed that the highest value resulting from the indicators average for managers is located in the alternative always with $84.94 \%$, followed by almost never with $11.11 \%$, almost always with $9.53 \%$ and sometimes with $7.94 \%$. On the other hand, for the employees the values were $48.85 \%$ in almost always, $31.95 \%$ in always, $20.77 \%$ in sometimes, $16.95 \%$ in never and $15.62 \%$ in almost never.

The means average values were of 4.69 for the managers, categorizing themselves as Very Adequate and 3.38 for the employees, corresponding to the Little Adequate alternative. These results, according to the employee's opinion are contrary to what Robbins ${ }^{3}$ refers to who states that defining an organizational structure should take into account the people who integrate it and those who could potentially integrate it, as part of their characteristics.

In that same order, Ferreira ${ }^{12}$, adds during the process of designing the structure, there must be a constant interaction between the conceptualization inherent in the executive organization, the personality and aptitudes of each of the organization members. It is not advisable to outline the organization chart first and then just start thinking about who will occupy each position of the same. It is equally important to consider the people characteristics and the organization, since they all form a set which are necessary for the effective company functioning. It is therefore necessary at present that organizations have highly capable managers to face the challenges that arise and be able to adapt to carry out the organization, assuming the changes to keep up with the demands demanded by their organization.

The analysis of the Organizational Behavior variable closure (Table 6), showed that for managers the highest percentage of answers coincides with the alternative always with $62.86 \%$, followed almost always with $21.41 \%$, almost never with $11.97 \%$, sometimes with $6.40 \%$ and never with $2.45 \%$. On the other hand, for employees, the mostly selected alternative was always $26.78 \%$, followed by never with $24.28 \%$, almost always with $22.65 \%$ almost never with $20.36 \%$ and sometimes with $15.06 \%$.

Similarly, the means values were 4.06 for managers categorizing the variable as Adequate, while for employees it was 2.80 coinciding with the category Adequate. As can be observed, these results show differences with respect to the opinions of both populations regarding the organizational behavior variable, observing the biggest difference in terms of the individual psychological variable dimension.

These results differ with what was proposed by Robbins ${ }^{3}$, who refers that organizational behavior is determined to a large extent by the acts and attitudes that people show in organizations. In this sense, the CO systematically studies the acts (or behaviors) and attitudes, which are employees performance fundamental determinants as they influence the organization productivity and therefore the results quality and quantity that each employee produces, and may affect the organizational objectives achievement.

It is necessary in this sense in organizations to study the different forms of work behavior, both individual and group, including the interrelations analysis between

Table 5. Organizational structure elements dimension

\begin{tabular}{|c|c|c|c|c|c|c|c|c|c|c|c|c|}
\hline \multirow[b]{3}{*}{ Indicators } & \multicolumn{10}{|c|}{ Alternatives (\%) } & & \\
\hline & \multicolumn{2}{|c|}{ Always } & \multicolumn{2}{|c|}{ Almost Always } & \multicolumn{2}{|c|}{ Sometimes } & \multicolumn{2}{|c|}{ Almost Never } & \multicolumn{2}{|l|}{ Never } & \multicolumn{2}{|c|}{ Means } \\
\hline & Man. & Emp. & Man. & Emp. & Man. & Emp. & Man. & Emp. & Man. & Emp. & Man. & Emp. \\
\hline Specialization & 83.33 & 20.77 & 11.11 & 13.04 & 5.56 & 39.61 & 0.00 & 18.36 & 0.00 & 8.21 & 4.77 & 3.19 \\
\hline $\begin{array}{l}\text { Departmenta- } \\
\text { lization }\end{array}$ & 77.77 & 21.26 & 16.67 & 32.85 & 5.56 & 16.43 & 0.00 & 18.84 & 0.00 & 10.63 & 4.72 & 3.35 \\
\hline Command chain & 77.77 & 72.46 & 11.11 & 21.74 & 11.11 & 5.80 & 0.00 & 0.00 & 0.00 & 0.00 & 4.66 & 4.66 \\
\hline Control section & 61.11 & 23.67 & 5.56 & 9.18 & 22.22 & 22.71 & 0.00 & 21.74 & 0.00 & 22.42 & 4.16 & 2.89 \\
\hline Formalization & 83.33 & 22.70 & 11.11 & 46.37 & 5.56 & 28.50 & 11.11 & 2.42 & 0.00 & 0.00 & 4.77 & 3.40 \\
\hline Centralization & 88.89 & 28.50 & 5.56 & 4.83 & 5.56 & 12.08 & 0.00 & 29.95 & 0.00 & 26.55 & 4.83 & 2.80 \\
\hline Complexity & 94.44 & 34.29 & 5.56 & 42.99 & 0.00 & 20.29 & 0.00 & 2.42 & 0.00 & 0.00 & 4.94 & 3.40 \\
\hline Average & 84.94 & 31.95 & 9.53 & 48.85 & 7.94 & 20.77 & 11.11 & 15.62 & 0.00 & 16.95 & 4.69 & 3.38 \\
\hline
\end{tabular}


Table 6. Organizational behavior variable closure

\begin{tabular}{|c|c|c|c|c|c|c|c|c|c|c|c|c|}
\hline \multirow[b]{3}{*}{ Dimensions } & \multicolumn{10}{|c|}{ Alternatives (\%) } & \multirow{2}{*}{\multicolumn{2}{|c|}{ Means }} \\
\hline & \multicolumn{2}{|c|}{ Always } & \multicolumn{2}{|c|}{ Almost Always } & \multicolumn{2}{|c|}{ Sometimes } & \multicolumn{2}{|c|}{ Almost Never } & \multicolumn{2}{|c|}{ Never } & & \\
\hline & Man. & Emp. & Man. & Emp. & Man. & Emp. & Man. & Emp. & Man. & Emp. & Man. & Emp. \\
\hline $\begin{array}{l}\text { Individual } \\
\text { psychological } \\
\text { variables }\end{array}$ & 46.23 & 2.65 & 45.43 & 3.55 & 7.55 & 9.89 & 0.75 & 36.15 & 1.78 & 40.03 & 3.59 & 2.08 \\
\hline $\begin{array}{l}\text { Organizational } \\
\text { design types }\end{array}$ & 57.41 & 45.75 & 9.26 & 15.55 & 3.70 & 14.51 & 24.07 & 9.31 & 5.56 & 15.86 & 3.90 & 2.95 \\
\hline $\begin{array}{l}\text { Organizational } \\
\text { structure elements }\end{array}$ & 84.94 & 31.95 & 9.53 & 48.85 & 7.94 & 20.77 & 11.11 & 15.62 & 0.00 & 16.95 & 4.69 & 3.38 \\
\hline Average & 62.86 & 26.78 & 21.41 & 22.65 & 6.40 & 15.06 & 11.97 & 20.36 & 2.45 & 24.28 & 4.06 & 2.80 \\
\hline
\end{tabular}

individuals and groups, their interaction with their environment (environment) and the behavior of some and others in order to know what the organization behavior is and to be able to take the appropriate corrective measures in order to reorient them.

\section{Conclusions}

Taking into account the results shown, one can conclude regarding the first objective oriented to identify the staff individual psychological variables, that there are opinion differences between the managers and employees population, indicating the first that the psychological variables such as perception, attitudes, personality and emotional intelligence are adequate, while employees reported that they manifest inadequately.

This is an unfavorable factor for the appropriate organizational behavior since the manager's treatment to his staff must obey the knowledge of the personality, perception and attitudes variables, as well as their relationship in the work behavior, since through them will be able to understand the behaviors reason and to use mechanisms that allow conducting the required actions.

Regarding the second objective, to describe the organizational design types, it is concluded that there are also discrepancies between the opinions regarding the simple structure indicator, where employees identify the presence of this organizational design type, indicating that they have little labor specialization and the authority is centralized in a single person.

On the other hand, with regard to the matrix structure indicator, there are also differences, where employees say that the characteristics of this design type are not adequate because the manager assumes the responsibilities of his position without requesting or having the support of others departments or experts for their activities development. However, with respect to the bureaucratic organizational design type, there is an opinions coincidence when referring both populations that the organizations studied are characterized by their extremely routine operational tasks, with centralized authority, little control amplitude and a centralized decision-making process tied to the command chain.

Finally, for the third objective, verify the organizational structure elements, the employees felt that they are not adequate. The greatest opinions discrepancy was observed in the control and centralization indicators where the employees showed the greatest number of negative responses, indicating that the control section is broad, that is to say that it is managed almost entirely by the manager and by its breadth, most employees respond only to this and are supervised by him, so there is less attention and supervision that can be provided.

On the other hand, in terms of centralization, employees said that decision-making is focused on the manager. These results are added to those obtained in the previous dimension, as it corresponds to a bureaucratic design, characterized by a centralized authority, which makes it difficult for innovative activities to be developed that favor a work environment oriented towards the organizational objectives achievement.

\section{References}

1. Fernández P. Empresas Familiares América, Europa y Asia: Una aproximación cuantitativa. 1a Edición. Ediciones Uniandes. Mérida, Venezuela; 2017. p. 1-156. PMCid: PMC5214345. 
2. Chiavenato I. Innovaciones de la Administración. Mc Graw Hill: México; 2010.

3. Robbins S. Administración. Pearson Educación de México: México D.F: 2007.

4. Padilla A, Hernández C, Ríos R. Los estudios organizacionales en América latina: Un diagnóstico con base en la difusión del campo de estudio en Colombia, Brasil y México. Documento del XX Congreso internacional de contaduría, administración e informática México D.F; 2015. p. 1-19.

5. Hernández R, Fernández C, Baptista P. Metodología de la investigación. 5ta Edición. Mc Graw-Hill: México; 2010.

6. Tamayo M. El proceso de la investigación científica. Editorial Limusa. México; 2007.p. 1-440. PMid: 17442634.

7. Ander E. Métodos y técnicas de investigación social: Técnica para recogida de datos e información. Lumen. Buenos Aires, Argentina; 2003. p. 1-381.
8. Bernal T. Metodología de la Investigación. Para administración, economía, humanidades y ciencias sociales. Editorial Pearson Educación. México; 2006. p. 1-286. PMid: 16837218.

9. Namakforoosh M. Metodología de la investigación. Segunda edición. Editorial Limusa: México; 2007.

10. Robbins S, Decenzo D. Fundamentos de administración: Conceptos esenciales y aplicaciones. Tercera edición. Pearson Educación: México; 2009. p. 1-550.

11. Ferreira H. Educar en la acción para aprender a emprender una organización. Ediciones Novedades Educativas de México S.A., México D.F.; 2006.

12. Alles M. Comportamiento Organizacional: Como lograr un cambio cultural a través de gestión por competencias. Granica: Buenos Aires; 2007. p. 1-544. 